\title{
Hypochlorous Acid - Analytical Methods and Antimicrobial Activity
}

\author{
Müjde Eryılmaz ${ }^{1^{\star}}$ and İsmail Murat Palabıyık ${ }^{2}$ \\ ${ }^{1}$ Department of Pharmaceutical Microbiology, ${ }^{2}$ Department of Analytical Chemistry, Faculty of Pharmacy, Ankara University, \\ 06100 Ankara, Turkey
}

*For correspondence: Email: meryilmaz@ankara.edu.tr; Tel: +90 3122033185

Received: 27 September 2012

Revised accepted: 5 January 2013

\begin{abstract}
Hypochlorous acid (HOCl) is produced by the human body's immune cells to fight infections. It is effective against a broad range of microorganisms. It is non-toxic, non-irritant and non-corrosive at proper usage concentrations. There are some available commercial products that contain $\mathrm{HOCl}$. However, its low storage stability constitutes a major challenge. This review considers the antimicrobial activity of $\mathrm{HOCl}$ and its methods of analysis.
\end{abstract}

Keywords: Antimicrobial activity, Hypochlorous acid, Analytical methods

Tropical Journal of Pharmaceutical Research is indexed by Science Citation Index (SciSearch), Scopus, International Pharmaceutical Abstract, Chemical Abstracts, Embase, Index Copernicus, EBSCO, African Index Medicus, JournalSeek, Journal Citation Reports/Science Edition, Directory of Open Access Journals (DOAJ), African Journal Online, Bioline International, Open-J-Gate and Pharmacy Abstracts

\section{INTRODUCTION}

Hypoclorous acid $(\mathrm{HOCl})$, a powerful oxidizer and deproteinizer produced by neutrophils, has a good microbicidal activity within these cells. It reacts with many biological molecules, especially thiol, thiolether, heme proteins, amino groups and carbonhydrates, as well as overcomes pathogens and fights infection [1-3]. $\mathrm{HOCl}$ has advantages over sodium hypochlorite $(\mathrm{NaOCl})$ and hydrogen peroxide $\left(\mathrm{H}_{2} \mathrm{O}_{2}\right)$ in that within its effective antimicrobial concentration range, it is non-irritating, non-sensitizing and cytotoxicity to mammalian cells is lower [1].

It can be synthesized by one of the three methods [3]:

(a) Hydrolysis of chlorine gas $\mathrm{Cl}_{2}+\mathrm{H}_{2} \mathrm{O} \rightarrow \mathrm{HOCl}+\mathrm{H}^{+}+\mathrm{Cl}^{-}$

(b) Electrolysis of salt solution $2 \mathrm{Cl}^{-}+2 \mathrm{e}^{-} \rightarrow \mathrm{Cl}_{2}(\mathrm{I})$

$$
\mathrm{Cl}_{2}+\mathrm{H}_{2} \mathrm{O} \rightarrow \mathrm{HOCl}+\mathrm{H}^{+}+\mathrm{Cl}^{-}(\mathrm{II})
$$

\section{(c) Acidification of hypochlorite $\mathrm{OCl}^{-}+\mathrm{H}^{+} \rightarrow \mathrm{HOCl}$}

The proportion of $\mathrm{HOCl}$ and hypochlorite ion $\left(\mathrm{OCl}^{-}\right)$in a solution depends on its $\mathrm{pH}$. The predominant species is $\mathrm{HOCl}$ between $\mathrm{pH} 3$ and 6. Within this $\mathrm{pH}$ range, the concentration of $\mathrm{HOCl}$ is optimal and its dissociation is minimal. At higher $\mathrm{pH}, \mathrm{OCl}^{-}$is formed, whereas at lower $\mathrm{pH}$, the solution exists as a mixture of chlorine $\left(\mathrm{Cl}_{2}\right)$ and $\mathrm{HOCl}$ in solution [4]. Due to the challenge of maintaining storage stability, a commercial pharmaceutical formulation containing pure $\mathrm{HOCl}$ has not been developed [1]. Studies have shown that stabilized $\mathrm{HOCl}$ displays rapid and concentration-dependent activity against clinically relevant microorganisms, as long as the effective $\mathrm{pH}$ range is maintained $[1,3,5-7]$. 


\section{COMMERCIAL PRODUCTS THAT CONTAIN $\mathrm{HOCl}$}

Mild acidic $\mathrm{HOCl}$ solutions, developed by acidifying $\mathrm{NaOCl}$ with $\mathrm{HCl}$ or electrolyzing $\mathrm{NaOCl}$ solutions, have been widely used as disinfectants [1]. NVC-101 is one of the commercially available product containing acidified and unbuffered solution of $\mathrm{HOCl}$ in saline and its concentration is low. The active ingredient of this product is primarily $\mathrm{HOCl}$ in equilibrium with a small amount of dissolved $\mathrm{Cl}_{2}$. NVC-101 containing $0.01 \%$ $\mathrm{HOCl}$ with a pH of 3.5 to 4.0 was demonstrated to be an effective topical antimicrobial agent when used for a brief period (15-30 min) and followed with another application. This was because of its rapid neutralization in the wound bed environment. If its effective $\mathrm{pH}$ range can be maintained in the clinical situation, this stabilized form of $\mathrm{HOCl}$ (NVC-101) could have potential application as an antimicrobial wound irrigation and treatment solution [8]. Wang et al [3] indicated that NVC-101 had rapid and broad spectrum antimicrobial activity against clinically relevant microorganisms in vitro and in vivo. In another study, Robson et al [8] reported that as opposed to other antimicrobials investigated in their study, NVC-101 controlled the tissue bacterial bioburden without inhibiting the wound healing process.

One of the commercial disinfectants containing $\mathrm{HOCl}$ is Medilox $\AA$, and is prepared by electrolysis of sodium chloride solution. Electrolysis yields super-oxidized water with $\mathrm{pH}$ of $5.0-6.5$ and an oxidation-reduction potential of $>950 \mathrm{mV}$ and containing about $30-50 \mathrm{ppm}$ of $\mathrm{HOCl}$ [5] . Choi and Kim [5] evaluated the antimicrobial activity of Medilox against several clinical isolates of bacteria (methicillinsusceptible Staphylococcus aureus, methicillinresistant Staphylococcus aureus (MRSA), Staphylococcus epidermidis, Enterococcus faecalis, Streptococcus pneumoniae, Salmonella typhi, Salmonella paratyphi A, Salmonella enteritidis, Shigella flexneri, Pseudomonas aeruginosa, Acinetobacter baumanii, Escherichia coli, Serratia marcescens, Klebsiella pneumoniae, Enterobacter cloacae, Citrobacter freundii, Stenotrophomonas maltophilia, Proteus mirabilis, Citrobacter freundii, Stenotrophomonas maltophilia, Proteus mirabilis, Chryseobacterium meningosepticum) and yeast (Candida albicans). They observed that all strains of bacteria and yeast were killed within 30 seconds after exposure to $30 \mathrm{ppm}$ of Medilox. Moreover, Bacillus subtilis was killed within 4 min after exposure to $30 \mathrm{ppm}$ of Medilox, but killed within $30 \mathrm{~s}$ in $50 \mathrm{ppm}$ of Medilox. This study showed that Medilox is effective against commonly isolated bacteria and yeast from hospital but was less effective against spore-forming bacteria.

Huang et al [9] evaluated the stability of Medilox and its disinfection effect on hands and on article surfaces. They stored Medilox for 90 days under room temperature and at the end of the period they determined its effective chlorine content, $\mathrm{pH}$ value and disinfection effect on hands and article surface. As a result, they found that its chlorine content decreased by $36 \%$, pH value by $17 \%$ and the average disinfection effect of the Medilox on hands and on article surface was over $90 \%$. Shi et al [4] evaluated the bactericidal effects of Medilox at neutral $\mathrm{pH}$. They found that MRSA, Acinetobacter baumannii and Streptococcus pneumoniae strains were killed within 1 min by Medilox. They indicated that Medilox has a quick and highly effective bactericidal action and it can be used for the effective disinfection of skin, instruments and surfaces.

Another $\mathrm{HOCl}$ containing disinfectant is Sterilox. It contains $\mathrm{HOCl}$ at a concentration of approximately $144 \mathrm{mg} / \mathrm{L}$ and free chlorine radicals. Its $\mathrm{pH}$ is $5.0-6.5$ and has an oxidationreduction potential of $>950 \mathrm{mV}$ [10]. It has been shown to be non-toxic to biological tissues and is claimed to be non-corrosive and non-damaging to endoscopes [11]. The antimicrobial activity of Sterilox has been tested against Clostridium difficile spores, Helicobacter pylori, vancomycin resistant Enterococcus species, Candida albicans and several Mycobacterium spp. According to the results, it was effective $(<2$ min) in achieving a 5 -log 10 reduction of pathogenic microorganisms (H. pylori, vancomycin resistant Enterococcus spp, $C$. albicans, $M$. avium, M. chelonei, $M$. xenopi and M. smegmatis) in the absence of organic loading. However, its biocidal activity was reduced in the presence of organic material (5\% horse serum) [12].

\section{ANALYTICAL METHODS FOR DETERMINA- TION OF HOCI}

Due to its low storage stability, determination of $\mathrm{HOCl}$ by different analytical methods has has assumed greater importance. They include the following.

\section{Spectroscopy}

$\mathrm{HOCl}$ and $\left(\mathrm{OCl}^{-}\right)$were determined by addition of bromine and fluorescein to natural (rea and fresh) waters. The resulting pink color was measured spectrophotometrically. Beside this, decrease in fluorescence intensity was evaluated in this study [13]. Isotopically, $\mathrm{HOCl}$ was 
determined by using the microwave spectrum for the determination of its molecular structure [14]. $\mathrm{HOCl}$ was also determined using spectrophotometry [15]. First, the samples were treated with tris(2-carboxyethyl)phosphine (TCEP), and then the, residual amount of TCEP was measured after reaction with 5,5'dithiobis(2-nitrobenzoic acid) via the final product, 2-nitro-5-thiobenzoate. The concentration of $\mathrm{HOCl}$ was calculated based on the oxidation of TCEP by $\mathrm{HOCl}$ in a 1:1 ratio.

In another technique, a specific ferrocene-based florescent probe was developed for $\mathrm{HOCl}$ [16]. This is based on the formation of a double bond between $\mathrm{HOCl}$ and ferrocene selectively in $\mathrm{pH}$ 7.4 , a condition that was achieved by a $100-$ fold fluorescence enhancement. The developed probe was applied to HeLa cells for fluorimetric imaging of $\mathrm{HOCl}$. Simultaneous determination of chlorine dioxide and $\mathrm{HOCl}$ in the bleaching process has also been achieved by a spectroscopic method [17]. Spectrophotometric measurement of $\mathrm{HOCl}$ and chlorine dioxide were carried out at $295 \mathrm{~nm}$ but the method was not successful for the determination of low levels of $\mathrm{HOCl}$. A specific and sensitive fluorescence method was developed for imaging of $\mathrm{HOCl}$ produced by a microbe [18]. Beside this, a method has also been developed using three water-soluble dihydrofluorescein-ether probes for the detection of $\mathrm{HOCl}$ via oxidation; these probes were applied to determine accumulated hypochlorous acid in organelles in a zebra fish model [19]. HOCl has also been detected by a $\mathrm{HOCl}$-promoted cyclization reaction based on fluorescence resonance energy transfer (FRET) signaling mechanism; the authors claimed that their study shed light on the development of new fluorescent $\mathrm{HOCl}$ probes [20]. Kim et al [21] developed a boron-dipyrromethene (BODIPY)based probe for the selective detection of $\mathrm{HOCl}$ in living cells.

\section{Electrochemistry}

$\mathrm{HOCl}$ concentration has been evaluated by deposition of copper on a gold-film electrode using potentiometric stripping analysis prior to being chemically oxidized by chlorine species [22]. In another study, $\mathrm{HOCl}$ was determined by electrochemically establishing an anode via coating a ferrite film on a substrate [23]. Limit of detection was $0.005 \mathrm{mg}$ of $\mathrm{Cl} / \mathrm{L}$ for $\mathrm{HOCl}$. Sournia-Saquet et al [24] developed an amperometric method for the determination of $\mathrm{HOCl}$ from drinking water and swimming pools. The reaction was evaluated via a reduction path using cylic voltammetry. A suitable potential, i.e., $400 \mathrm{mV}$, was determined by chronoamperometry and the linear response range was determined as $1-50 \mathrm{ppm}$. This method was compared with an iodometric method. In a similar study, $\mathrm{HOCl}$ was determined using cylic voltammetry for measurement of residual levels in tap water; the reaction was monitored via a reduction path at + $0.3 \mathrm{~V}$ versus SCE [25]. In this study, gold electrode was applied to the flow injection analysis device and the linear calibration concentration range was found to be $0.05-2.5$ $\mathrm{mg} \mathrm{L}^{-1}$ while the relative standard deviation was $2.1 \%$. These results were compared with a photometric method using o-toluidine. In another work, Takeshi and Yaegashi [26] developed an electrochemical sensor for the determination of $\mathrm{HOCl}$ in electrolyzed water. The working electrode was B-doped diamond electrode and the reference electrode an SCE. Gobet and Rychen [27] took a patent for an electrochemical sensor for the determination of $\mathrm{HOCl}$ in water.

\section{Titrimetric and Thermochemical Methods}

Klimenko [28] and Salzer [29] developed a titrimetric method based on the reaction with potassium iodide. $\mathrm{HOCl}$ has also been determined by titration with aqueous methyl orange of a minimum of $0.5 \mathrm{mg} \mathrm{Cl} / \mathrm{l}$ ) [30] while Stojkovic et al [31] developed a method for the determination of dissociation constant based on the measurement of $\mathrm{pH}$ in $5 \mathrm{M} \mathrm{NaCl}$. The values were measured from the intercept and slope of a straight line and from thermodynamic measurement. Denis [32] carried out thermochemical studies on hypobromous and $\mathrm{HOCl}$ in which Delta $\mathrm{H}$ degrees were determined.

\section{CONCLUSION}

Although $\mathrm{HOCl}$ is a potent antimicrobial agent and has advantages such as non-toxicity in biological tissues and environmentally friendly, it has limited applications due to its decreasing antimicrobial efficacy in the presence of organic matter and low storage stability. $\mathrm{HOCl}$ is present in multiply used containers as commercial products and following to each using, amount of $\mathrm{HOCl}$ is decreased. Hence, the determination of $\mathrm{HOCl}$ with various analytical methods are necessary.

\section{REFERENCES}

1. Kunawarote $S$, Nakajima $M$, Shida $K$, Kitasako $Y$, Foxton RM, Tagami J. Effect of dentin pretreatment with mild acidic $\mathrm{HOCl}$ solution on microtensile bond strength and surface $\mathrm{pH}$. J Dent 2010; 38: 261-268.

2. Pattison DI, Davies MJ. Absolute rate constants for the reaction of hypochlorous acid with protein side chains and peptide bonds. Chem Res Toxicol.2001; 14(10): 1453-1564. 
3. Wang L, Bassiri M, Najafi K, Yang J, Khosrovi B, Hwong W, Barati E, Belisle B, Celeri C, Robson MC Hypochlorous acid as a potential wound care agent Part I. Stabilized Hypochlorous Acid: A Component of the inorganic armamentarium of innate immunity. J.Burns Wounds 2007; 6: 65-79.

4. Shi Li-ke, Wang Yan, Wang Yue, Liu Yan, Qi Xiao-min, Zhao Gui-rong. Disinfection efficacy of Medilox Super-oxidized water with neutral $\mathrm{pH}$. Chinese Journal of Nosocomial Infections 2009; 24: 3370 3372.

5. Chai TY, Kim WB. Bactericidal Effect of Disinfectant a Super-oxidized Water, Medilox $\AA$. Korean $J$ Nosocomial Infect Control 1998; 3(1): 1-6.

6. Landa-Solis C, Gonzales-Espinosa D, Guzman-Soriano $B$, Snyder M, Reyes-Teran G, Torres K, Gutierrez $A A$. Microcyn ${ }^{T M}$ : a novel super-oxidized water with neutral $\mathrm{pH}$ and disinfectant activity. J Hosp Infect 2005; 61(4): 291-299.

7. Marcinkiewicz J, Chain B, Nowak B, Grabowska A, Bryniarski K, Baran J. Antimicrobial and cytotoxic activity of hypochlorous acid: interactions with taurine and nitrite. Inflamm Res 2000; 49: 280-289.

8. Robson MC, Payne WG, Ko F, Mentis M, Donati G, Shaffi SM, Culverhouse $S$, Wang $L$, Khosrovi $B$, Najafi R, Cooper DM, Bassiri M. Hypochlorous Acid as a Potential Wound Care Agent Part II. Stabilized Hypochlorous Acid:Its Role in Decreasing Tissue Bacterial Bioburden and Overcoming the Inhibition of Infection on Wound Healing. J Burns Wounds 2007; 6: 80-90.

9. Huang $T$, Zhao S, Weng Y, Deng Z. Stability of Medilox electrolyzed oxidizing water and its disinfection effect on hand and on article surface. J Pharm Pract 2009; 27:370-372

10. Rutala WA, Weber DJ. New Disinfection and Sterilization Methods. Emerg Infect Dis 2001; 7(2): 348-353.

11. Fraise AP. Choosing disinfectants. J Hosp Infect 1999; 43: $255-264$

12. Shetty $N$, Srinivasan $S$, Holton J, Ridgway GL. Evaluation of microbicidal activity of a new disinfectant: Sterilox 2500 against Clostridium difficile spores, Helicobacter pylori, vancomycin resistant Enterococcus species, Candida albicans and several Mycobacterium species. J Hosp Infect 1999; 41(2): 101-105.

13. Williams $P M$, Robertson KJ. Determination of hypochlorous acid plus hypochlorite ion by bromination of fluorescein. Journal-Water Pollution Control Federation 1980; 52(8): 2167-2173.

14. Anderson WD, Gerry MCL, Davis RW. The microwavespectrum of isotopically substituted hyporchlorous acid-determination of the molecular-structure. J Mol Spectrosc 1986; 115(1): 117-130.

15. Han J, Chu TC, Han G, Browne J, Brown I, Han P. Spectrophotometric assay for hypochlorite/hypochlorous acid using tris(2carboxyethyl)phosphine. Microchem J 1998; 58(2): 218-224.

16. Chen SM, Lu JX, Sun CD, Ma HM. A highly specific ferrocene-based fluorescent probe for hypochlorous acid and its application to cell imaging. Analyst 2010; 135(3): 577-582.

17. Wang $Q$, Chen KF, Li J, Xu J, Liu SS. Simultaneous determination of chlorine dioxide and hypochlorous acid in bleaching system. Bioresources 2011; 6(2): 1868-1879.

18. Chen $X$, Lee $K$, Ha E, Lee KM, Seo YY, Choi HK, Kim HN, Cho C, Lee SY, Lee W, Yoon J. A specific and sensitive method for detection of hypochlorous acid for the imaging of microbe-induced $\mathrm{HOCl}$ production. Chem Commun 2011; 47: 4373-4375.

19. Zhou Y, Li J, Chu K, Liu K, Yao C, Li J. Fluorescence turn-on detection of hypochlorous acid via $\mathrm{HOCl}$ promoted dihydrofluorescein-ether oxidation and its application in vivo. Chem. Commun 2012; 48: 4677-4679.

20. Yuan L, Lin W, Xie Y, Chen B, Song J. Fluorescent detection of hypochlorous acid from turn-on to FRET-based ratiometry by a $\mathrm{HOCl}$-mediated cyclization reaction. Chemistry 2012; 18(9): 27002706.

21. Kim T, Park S, Choi Y, Kim, Y. A BODIPY-Based probe for the selective detection of hypochlorous acid in living cells. Chem-Asian J 2011; 6(6): 1358-1361.

22. Xie $Y$, Huber CO. Potentiometric stripping analysis using Copper (I) and determination of chlorine species. Anal Chem 1991; 63(3): 208-212.

23. Abe M, Ekusa K. Anode and device for determination of hypochlorous acid concentration. April 1996; Jpn. Kokai Tokkyo Koho JP 08094572.

24. Sournia-Saquet $A$, Lafage $B$, Savall A. Determination of hypochlorous acid by amperometric measurement with a microelectrode. Cr Acad Sci II C 1999; 2(910): 497-505

25. Iketake H, Yamada A. Determination of residual chlorine by flow injection/electrochemical dedector. Bunseki Kagaku 1999: 48(12); 1123-1127.

26. Takeshi $R$, Yaegashi $M$. Air disinfection apparatus having water electrolysis unit and electrochemical sensor for determination of hypochlorous acid in electrolyzed water. October 2010. Jpn. Kokai Tokkyo Koho JP 2010227381.

27. Gobet J, Rychen P. Electrochemical sensor for the determination of hypochlorus acid in water. November 2002. EP 1260813. 2008. CH 697478.

28. Klimenko E. A new simple method to the proof and determination of hypochlorous acid (machine translation). Zeitschrift Fuer Analytische Chemie 1904; 42: 718-724.

29. Salzer T. Detection of hypohlorous acid in chlorine water. Chem Centr 1890, ii, 472; Pharm. Zeit. 35: 457.

30. Molt EL. Determination of hypochlorous acid by titration with methyl orange. Chemisch Weekblad 1956; 52: 265-267.

31. Stojkovic D, Jaksis MM, Nikolic BZ. Determination of hypochlorous acid dissociation constant by the straight line method. Glasnik Hemijskog Drustva Beograd 1969; 34(2-4): 171-180.

32. Denis PA. Thermochemistry of the hypobromous and hypochlorous acids, $\mathrm{HOBr}$ and $\mathrm{HOCl}$. J Phys Chem A 2006; 110(17): 5887-5892. 